\title{
Pengaruh Media Audio Visual Terhadap Kemampuan Bercerita Anak Usia 5-6 Tahun
}

\author{
Siti Pujiah ${ }^{1}$, Angger Prima Widiasih ${ }^{2}$ \\ 1,2Program Studi Pendidikan Guru Pendidikan Anak Usia Dini; Fakultas \\ Keguruan Dan Ilmu Pendidikan; Universitas Muhammadiyah Tangerang \\ ${ }^{1}$ sitipujiah1124@gmail.com, ${ }^{2}$ widiasih.angger@gmail.com
}

\begin{abstract}
Abstrak
Penelitian ini bertujuan untuk mengetahui Pengaruh Media Audio Visual Terhadap Kemampuan Bercerita. Penelitian ini dilakukan dengan kelompok, yaitu kelompok eksperimen pada B1 dan kelompok kontrol pada kelas B2. Subjek penelitian yang dilibatkan dalam penelitian ini berjumlah 14 siswa kelas B1 dan 14 siswa kelas kontrol B2, jumlah keseluruhan dalah 28 siswa TKQ Al-Hikmah Lebak Wangi Tangerang. Metode yang digunakan dalam penelitian adalah Quasi Eksperimen, penelitian ini difokuskan pada siswa kelas B1 dan B2. Teknik pengumpulan data yang digunakan adalah obesrvasi dan test. Dapat diketahui bahwa hasil belajar siswa kelompok eksperimen lebih baik dibandingkan dengan kelompok kontrol. Hasil ditunjukan dari nilai rata-rata Pretest kelompok eksperimen sebesar 19,64. Setelah diberikan perlakuan dengan media audio visual, nilai rata-rata Postest kelompok eksperimen mengalami peningkatan menjadi 23,36. Sedangkan nilai rata-rata Pretest kelompok kontrol adalah 17,93. Nilai rata-rata Postest kelompok kontrol mengalami peningkatan menjadi 21,93. Berdasarkan hasil penelitian di atas dapat disimpulkan bahwa media pembelajaran audio visual memiliki pengaruh terhadap kemampuan bercerita.
\end{abstract}

Kata Kunci: Audio Visual, Kemampuan Bercerita, Anak Usia 5-6 Tahun

\section{Pengantar}

Anak usia dini merupakan anak pada tahapan 0-8 tahun. Pada masa ini sering disebut dengan masa keemasan atau golden age. Bahwa masa keemasan ini merupakan periode sensitif (sensitive periods) pada anak, selama masa inilah anak secara khusus mudah menerima stimulus-stimulus dari lingkungannya, baik dari 
"Ceria"

\section{Jurnal Program Studi Pendidikan Anak Usia Dini}

lingkungan keluarga maupun teman sebayanya Montessori dalam Sujiono (2009, h. 54).

Pada masa keemasan ini diperlukan perhatian khusus, karena stimulasi yang diberikan dapat mempengaruhi perkembangan otak anak dan kemampuan akademiknya pada masa yang akan datang. Usia keemasan merupakan masa dimana anak mulai peka untuk menerima berbagai stimulus dan berbagai upaya pendidikan dari lingkungannya.

Anak usia dini memiliki karakteristik yang berbeda-beda pada tiap usia. Hal tersebut di atur dalam Permendiknas No.137 mencantumkan poin standar Tingkat Pencapaian Perkembangan anak, salah satunya adalah pada aspek bahasa. Bahasa adalah suatu bentuk atau komunikasi baik lisan, tertulis maupun isyarat yang berdasarkan pada sebuah sistem simbol. Dengan bahasa yang mereka miliki perkembangan kosakata akan berkembang dengan cepat.

Bahasa berkembang dimulai dengan peniruan bunyi dan meraban. Perkembangan selanjutnya berhubungan erat dengan perkembangan kemampuan intelektual dan sosial. Bahasa merupakan alat untuk berpikir Syaodih dalam Susanto (2011, h. 73). Karena berpikir juga merupakan suatu proses memahami dan melihat suatu hubungan. Proses ini tidak mungkin dapat berlangsung dengan baik tanpa alat bantu, yaitu bahasa.

Bahasa juga merupakan alat berkomunikasi dengan orang lain dan kemudian berlangsung dalam suatu interaksi sosial. Keterampilan bahasa juga penting dalam rangka pembentukan konsep, informasi, dalam pemecahan masalah. Karena melalui bahasa pula kita dapat memahami pada komunikasi pikiran dan perasaan. Bahasa adalah alat untuk berfikir, mengekspresikan diri dan berkomunikasi. Kemampuan dapat disebut juga tenaga atau daya kekuatan untuk melakukan suatu perbuatan.

Hasil observasi dilapangan diketahui, bahwa kemampuan bahasa anak dalam kegiatan bercerita anak di TKQ Al-Hikmah masih belum berkembang secara optimal. Hal ini teramati sebagian besar anak yang belum mampu 
"Ceria"

Jurnal Program Studi Pendidikan Anak Usia Dini

melakukan kegiatan bercerita. Pada kelompok B1 dari 14 orang anak 10 anak yang kemampuan berceritanya belum berkembang dengan baik dan 4 anak sudah berkembang, dan kelompok B2 dari 14 anak, 9 anak yang kemampuan berceritanya belum berkembang dengan baik dan 5 anak sudah berkembang kemampuan berceritanya.

Pada peraturan Menteri Pendidikan dan Kebudayaan no 137 tahun 2014 tentang Standar Nasional Pendidikan Anak Usia Dini terdapat beberapa tingkat pencapaian perkembangan pada anak usia Taman Kanak-Kanak (usia 5-6 tahun) dalam lingkup perkembangan bahasa. Berikut ini beberapa tingkat pencapaian perkembangan yang terkait dengan karakteristik kemampuan bercerita pada anak antara lain: (1) Berkomunikasi secara lisan, memiliki perbendaharaan kata, serta mengenal simbol-simbol untuk persiapan membaca menulis dan berhitung; (2) Menjawab pertanyaan yang lebih kompleks; (3) memiliki lebih banyak kata-kata untuk mengekspresikan ide pada orang lain; (4) Melanjutkan sebagian cerita / dongeng yang telah diperdengarkan; (5) Menunjukan pemahaman konsepkonsep dalam buku cerita. Jadi pada usia ini anak sudah dapat menunjukan rasa percaya diri ketika sedang melakukan kegiatan bercerita.

Kemampuan merupakan daya untuk melakukan suatu tindakan sebagai hasil dari pembawaan dan latihan, seorang dapat melakukan sesuatu dikarenakan ada kemampuan yang dimilikinya (Susanto 2011:97). Kemampuan dapat disebut sebagai tenaga atau daya pada diri seseorang yang dimilikinya. Kemampuan yang ada pada diri seseorang dapat juga menjadikan hasil keterampilan

Selain itu, kemampuan juga dapat melihat tingkat kemampuan pada seorang individu. Kemampuan adalah tingkat pengetahuan ataupun tingkat keterampilan anak dalam bidang tertentu (Fridani, dkk 2014:1.8). Pengetahuan dapat dilihat dari individu melalui kemampuan yang seseorang miliki. Dengan kemampuan dapat menghasilkan keterampilan yang dapat dilihat pada individu. 
"Ceria"

\section{Jurnal Program Studi Pendidikan Anak Usia Dini}

Bercerita merupakan proses kereatif pada anak, yang dapat mengasah dalam proses perkembangannya. Bercerita juga merupakan aktivitas menuturkan sesuatu yang mengisahkan tentang perbuatan, pengalaman, atau kejadian yang sungguh-sungguh terjadi maupun hasil rekaan (Rahayu, 2013, h. 80). Bercerita dikatakan sebagai tuturan atau menuturkan sesuatu melalui perkataan yang terjadi, yaitu menyampaikan gambaran tentang kejadian tertentu.

Bercerita juga merupakan salah satu metode untuk mendidik anak. Bercerita kepada anak memainkan peranan penting bukan saja dalam menumbuhkan minat dan kebiasaan membaca, tetapi juga dalam mengembangkan bahasa dan fikiran anak (Risaldy 2015:74). Bercerita bagi anak dapat mengembagkan bahasa yang digunakan oleh anak. Dengan bercerita juga anak dapat menampilkan peranan sesuai yang ia pernakan, dari gerak dan mimik wajah.

kemampuan bercerita, dengan bercerita anak dapat mengasah keterampilan berbicara ketika berkomunikasi dengan orang lain. Bercerita merupakan suatu perbuatan atau suatu kejadian yang disampaikannya secara lisan kepada orang lain, melalui cerita, guru ataupun orang tua dapat memberikan pelajaran kepada anak-anak, memberikan contoh yang baik melalui cerita-cerita yang menarik, cerita yang disampaikan bisa berupa pengalaman, film/video, buku dongeng dan lainya. Kemampuan bercerita ialah suatu keahlian seseorang yang ada sejak lahir dalam mengembangkan keterampilannya dan dapat melatih bicara pada anak.

Dalam penelitian ini peneliti memilih media audio visual untuk mengembangkan kemampuan bercerita anak. tujuannya yang ingin dicapai adalah untuk mengembangkan kemampuan bercerita pada anak.

Media audio visual merupakan media yang mempunyai dua unsur yakni unsur suara dan unsur gambar. Media ini dianggap paling efektif dan sangat menarik dibandingkan dengan media audio saja ataupun media visual saja. Media audio visual terbagi menjadi dua jenis, jenis pertama dilengkapi fungsi 
"Ceria"

Jurnal Program Studi Pendidikan Anak Usia Dini

peralatan suara dan gambar dalam satu unit, dinamakan media audio visual murni, seperti film gerak bersuara dan video, jenis kedua adalah media audio visual tidak murni yang kita kenal dengan OPH dan alat visual lainnya (Munadi, 2013, h. 113)

Media audio visual merupakan media yang mempunyai dua unsur didalamnya. Media audio visual merupakan kombinasi audio dan visual atau bisa disebut media pandang dengar, audio visual akan menjadikan penyajian bahan ajar kepada siswa semakin lengkap dan optimal (Hamdani, 2011, h. 249). Jadi media ini dapat menggunakan kemampuan penglihatan dan pedengaran dari para penggunanya. Media ini juga termasuk media yang memberikan pengalaman belajar pada siswa, karena mampu mengaktifkan dua indera sekaligus.

Pemanfaatan media audio visual di dalam proses pembelajaran akan sangat mempengaruhi kemampuan bercerita . Sehingga kemampuan bercerita anak di TKQ Al-Hikmah masih belum berkembang. Untuk itu, guru perlu menggunakan media pembelajaran yang dapat mempengaruhi keterampilan bicara khususnya dalam bercerita agar kemampuan anak dapat meningkat. Disini peneliti akan melakukan kegiatan bercerita dengan menggunakan media audio visual (Video).

Penggunaan media audio visual ini diharapkan dapat mempengaruhi kemampuan bercerita anak. dalam teori diatas dijelaskan bercerita dengan menggunakan media audio visual sangat memudahkan anak dalam bercerita. Dengan menggunakan media audio visual anak pasti lebih tertarik ketika dalam proses pemebelajaran, karena dengan menggunakan media anak bisa lebih fokus dalam memperhatikan kegiatan tersebut. Setelah anak melihat proses bercerita yang menggunkan media, nanti anak diminta untuk menceritakan kembali cerita yang telah mereka tonton dengan menggunakan bahasa mereka sendiri. Dan guru menilai apakah terdapat pengaruh ketika bercerita dengan menggunakan media dan bercerita dengan metode ceramah. 
"Ceria"

Jurnal Program Studi Pendidikan Anak Usia Dini

\section{Metode}

Pendekatan penelitian ini dilakukan dengan menggunakan penedekatan kuantitatif, sedangkan jenis metode penelitian yang digunakan adalah Quasi Eksperimen, dengan subjek penelitian yaitu anak usia (5-6 tahun) di TKQ AlHikmah Lebak Wangi Tangerang.

Metode penelitian yang digunakan adalah quasi eksperimen dengan jenis Nonequivalent Control Group Design. Peneliti menggunakan dua kelompok yang terdiri atas kelompok eksperimental yang dibeli perlakuan dengan menggunakan media audio visual dan kelompok kontrol yang tidak diberi perlakuan/konvesional. Pada penelitian ini kelompok eksperimen maupun kontrol tidak dipilih secara random. Instrument yang digunakan dalam penelitian ini berupa lembar penilaian berupa daftar checklist, observasi dan tes (Pretes, Treatment, dan Postes). Teknis analisis yang dipakai adalah uji-t. Sebelum menghitung uji-t, terlebiqqh dahulu dilakukan uji prasyarat analisis data yaitu uji normalitas dan uji homogenitas, sedangkan teknik analisis data yang digunakan teknik analisis statistik deskriftif, seperti: a). Tabel distribusi frekuensi, b). Diagram histogram, c). Diagram ogive, d). Menentukan mean (rata-rata), e). Menentukan modus, f). Menentukan median, g). Simpangan baku, h). Uji normalitas, i). Uji homogenitas, j). Uji T Separated Varians.

\section{Hasil dan Pembahasan}

Penelitian ini dilakukan di Tkq Al-Hikmah pada penelitian ini di gunakan dua kelas sampel. Kelas B1 sebagai kelas eksperimen yang di ajar dengan menggunakan media audio visual, sedangkan kelas B2 sebagai kelas kontrol yang di ajar dengan menggunakan metode pembelajaran konvensional. Penelitian dilakukan selama 4 minggu dengan tatap mka sebanyak 6 kali pertemuan. Pokok bahasan yang diajarkan pada penelitian ini adalah perkembangan kemampuan bercerita menggunakan media audio visual. 
"Ceria"

Jurnal Program Studi Pendidikan Anak Usia Dini

Berdasarkan hasil penelitian pretes, tretment dan postes pada kelas ksperimen dan kelas kontrol terjadi peningkatan pada kemampuan bercerita anak usia 5-6 tahun. Berikut ini perhitungan data statistik awal diperoleh nilai pretes dan postes pada kelompok eksperimen dan kontrol. Berikut ini adalah nilai pretes dan postes kelompok eksperimen dan kontrol yang akan di sajikan dalam bentuk tabel distribusi frekuensi, histogram, poligon dan diagram ogive.

Tabel 1

Rangkuman Pretest Kelas Eksperimen dan Kelas Kontrol

\begin{tabular}{lcc}
\hline \multicolumn{1}{c}{ Statistik } & \multicolumn{2}{c}{ Kelas } \\
\cline { 2 - 3 } & Eksperimen & Kontrol \\
\hline Nilai terendah & 16 & 15 \\
Nilai tertinggi & 25 & 24 \\
Mean/rata-rata hitung & 19,64 & 17,93 \\
Modus & 18,25 & 15,21 \\
Median & 18,5 & 14,9 \\
Varians (S') & 5,03 & 3,52 \\
Simpangan baku (Sd) & 2.24 & 1,88 \\
\hline
\end{tabular}

Berdasarkan hasil analisis data pretest nilai terendah pada kelas eksperimen adalah 16 dan nilai tertinggi 25, sedangkan pada kelas kontrol nilai terendah adalah 15 dan nilai tertinggi adalah 24. Selanjutnya rata-rata kelas eksperimen adalah 19,64 dan rata-rata pada kelas kontrol 17, 93, data tersebut menggambarkan kondisi awal kelas sebelum diberikan tritment.

Tabel 2

Rangkuman Postest Kelas Eksperimen dan Kelas Kontrol

\begin{tabular}{lcc}
\hline \multicolumn{1}{c}{ Statistik } & \multicolumn{2}{c}{ Kelas } \\
\cline { 2 - 3 } & Eksperimen & Kontrol \\
\hline Nilai terendah & 20 & 19 \\
Nilai tertinggi & 29 & 28 \\
Mean/rata-rata hitung & 23,36 & 21,93 \\
Modus & 22,17 & 20,83 \\
Median & 22 & 21,1 \\
Varians (S & 3,52 & 4,42 \\
Simpangkan baku (Sd) & 1,88 & 2,10 \\
\hline
\end{tabular}


"Ceria"

\section{Jurnal Program Studi Pendidikan Anak Usia Dini}

Berdasarkan hasil analisis data pretest nilai terendah pada kelas eksperimen adalah 20 dan nilai tertinggi 29, sedangkan pada kelas kontrol nilai terendah adalah 19 dan nilai tertinggi adalah 28. Selanjutnya rata-rata kelas eksperimen adalah 23,36 dan rata-rata pada kelas kontrol 21, 93, data tersebut menggambarkan kondisi awal kelas setelah diberikan tritment.

Untuk menguji apakah sampel yang diambil berdistribusi normal atau tidak maka digunakan uji Liliefors.

Tabel 3

Uji NormalFitas Pretest Kelas Eksperimen

\begin{tabular}{|c|c|c|c|c|c|c|c|c|c|c|c|c|}
\hline No & Interval & $\mathrm{fi}$ & fk & $x i$ & fi.xi & $(x i-\dot{x})^{2}$ & $f i(x i-\dot{x})^{2}$ & zi & ztabel & $\mathrm{F}(\mathrm{zi})$ & S(zi) & $|F(z i)-S(z i)|$ \\
\hline 1 & $16-17$ & 2 & 2 & 15.5 & 31 & 9,88 & 19,76 & $-1,54615$ & 0.4382 & 0.0618 & 0.14 & -0.0811 \\
\hline 2 & 18-19 & 5 & 7 & 17.5 & 87,5 & 1,31 & 6,53 & -0.56224 & 0.2123 & 0.2877 & 0.50 & -0.2123 \\
\hline 3 & $20-21$ & 4 & 11 & 19.5 & 78 & 0.73 & 2,94 & 0.421677 & 0.1628 & 0.6628 & 0.79 & -0.1229 \\
\hline 4 & $22-23$ & 3 & 14 & 21.5 & 64,5 & 8,16 & 24,49 & 1.40559 & 0.4192 & 0.9192 & 1.00 & -0.0808 \\
\hline 5 & $24-25$ & 0 & & 23.5 & 0 & 23,59 & 0 & & & & & \\
\hline$\Sigma$ & & 14 & & & 261 & & 53,71 & & & & & \\
\hline
\end{tabular}

karena nilai $\mathrm{L}$ hitung $=-0,2123<\mathrm{L}$ tabel 0,227 , maka dapat disimpulkan bahwa data berdistribusi normal.

Berdasarkan tabel diatas terlihat bahwa liliefors hitung kelas eksperimen lebih kecil (Lo) dari liliefors tabel (LK) maka sampel berdistribusi normal. Demikian juga pretest kelas kontrol, nilai liliefors hitung lebih kecil (Lo) dari liliefors tabel maka sampel berdistribusi normal.

Tabel 4

Uji Normalitas Postest Kelas Eksperimen

\begin{tabular}{ccccccccccccc}
\hline No & Interval & $\mathbf{f i}$ & $\mathbf{f k}$ & $\mathbf{x i}$ & $\mathbf{f i . x i}$ & $\mathbf{( x i - \dot { \mathbf { x } } ) ^ { \mathbf { 2 } }}$ & $\mathbf{f i}(\mathbf{x i - \dot { \mathbf { x } }})^{\mathbf{2}}$ & $\mathbf{z i}$ & $\mathbf{z t a b e l}$ & $\mathbf{F}(\mathbf{z i})$ & $\mathbf{S}(\mathbf{z i})$ & $|\mathbf{F}(\mathbf{z i})-\mathbf{S}(\mathbf{z i})|$ \\
\hline $\mathbf{1}$ & $20-21$ & 2 & 2 & 19.5 & 39 & 8,16 & 16,33 & -1.52362 & 0.4357 & 0.0643 & 0.14 & -0.0786 \\
$\mathbf{2}$ & $22-23$ & 6 & 8 & 21.5 & 129 & 0.73 & 4,41 & $-0,45709$ & 0.1736 & 0.3264 & 0.57 & -0.2450 \\
$\mathbf{3}$ & $24-25$ & 4 & 12 & 23.5 & 94 & 1,31 & 5,22 & 0,609449 & 0.2257 & 0.7257 & 0,86 & -0.1314 \\
$\mathbf{4}$ & $26-27$ & 2 & 14 & 25.5 & 51 & 9,88 & 19,79 & 1,675986 & 0,4525 & 0,9525 & 1,00 & $-0,0475$ \\
$\mathbf{5}$ & $28-29$ & 0 & & 27.5 & & 26,45 & 0.00 & & & & & \\
\hline$\Sigma$ & & 14 & & 313 & & 45,71 & & & & & \\
\hline
\end{tabular}


"Ceria"

Jurnal Program Studi Pendidikan Anak Usia Dini

Karena nilai Lhitung $=-0.3564<$ Ltabel 0.173 , maka dapat disimpulkan bahwa data berdistribusi normal.

Berdasarkan tabel diatas terlihat bahwa liliefors hitung kelas eksperimen lebih kecil (Lo) dari liliefors tabel (LK) maka sampel berdistribusi normal. Demikian juga postest kelas kontrol, nilai liliefors hitung lebih kecil (Lo) dari liliefors tabel maka sampel berdistribusi normal.

Homogenitas dari hasil pengujian data pretes diperoleh hasil sebagai berikut:

Tabel 5

Hasil Uji Homogenitas Pretes

\begin{tabular}{cc}
\hline Fhitung & Ftabel \\
\hline $\mathbf{1 . 2 2}$ & 2,48 \\
\hline
\end{tabular}

Berdasarkan tabel diatas terlihat bahwa Fhitung lebih kecil dari $F_{\text {tabel, }}$ menurut kriteria homogenitas jika $F_{\text {hitung }}<\mathrm{F}_{\text {tabel }}$ Ho diterima, maka varian kedua sampel homogen, dapat disimpulkan bahwa kedua varian berasal dari populasi yang homogen.

Tabel 6

Hasil Uji Homogenitas Postes

\begin{tabular}{cc}
\hline Fhitung & Ftabel \\
\hline 1.26 & 2,48 \\
\hline
\end{tabular}

Berdasarkan tabel diatas terlihat bahwa $\mathrm{F}_{\text {hitung }}$ lebih besar dari $\mathrm{F}_{\text {tabel, }}$ menurut kriteria homogenitas jika $F_{\text {hitung }}>F_{\text {tabel }}$ Ho ditolak, maka varian kedua sampel tidak homogen, dapat disimpulkan bahwa kedua varian berasal dari populasi yang tidak homogen.

Tabel 7

Uji rata-rata dua pihak postes

\begin{tabular}{ccccccccc}
\hline \multicolumn{2}{l}{ Kelas Eksperimen } & \multicolumn{4}{c}{ Kelas Kontrol } & thitung & Ttabel \\
\hline$\dot{\mathbf{x}}$ & $\mathrm{Sd}$ & $\mathrm{S}^{2}$ & $\dot{\mathrm{x}}$ & $\mathrm{Sd}$ & $\mathrm{S}^{2}$ & 1.932 & 1.706 \\
\hline
\end{tabular}


"Ceria"

Jurnal Program Studi Pendidikan Anak Usia Dini

\begin{tabular}{llllll}
$\mathbf{2 3 . 3 6}$ & 2.10 & 4.42 & 21.93 & 1.88 & 3.52 \\
\hline
\end{tabular}

Berdasarkan tabel diatas terlihat nilai thitung lebih besar dari nilai tabel maka Ho ditolak, sehingga berdasarkan kriteria pengujian maka terdapat perbedaan ratarata postes kemampuan bercerita di kelas eksperimen dan kelas kontrol.

Berdasarkan hasil penelitian yang dilakukan peneliti dengan menggunakan media audio visual, terdapat perbedaan yang terjadi pada kelas eksperimen dan kontrol, yaitu terjadi peningkatan kemampuan bercerita pada kelas eksperimen dibandingkan dengan kelas kontrol.

\section{Kesimpulan}

Berdasarkan hasil analisis data yang dilakukan maka dapat diambil kesimpulan. Terdapat perbedaan yang signifikan hasil belajar antara siswa yang menggunakan media audio visual dengan siswa yang menggunakan metode konvesional. Dengan adanya perbedaan yang signifikan ini menunjukan bahwa pengguna media audio visual lebih efektif dibandingkan dengan metode konvesional dalam meningkatkan kemampuan bercerita.

Bercerita dengan menggunakan media audio visual ternyata lebih efektif, karena dengan bantuan media audio visual siswa menjadi lebih memahami dan lebih fokus ketika mendengarkan cerita, dan media audio visual juga dapat mengeluarkan suara dan terlihat juga gambarnya.

Proses belajar mengajar sangat menentukan prestasi dan motivasi bagi siswa dalam belajar, oleh karena itu guru harus terus berupaya menciptakan pembelajaran yang efektif, pengunaan media audio visual dalam pembelajaran khususnya dalam kemampuan bercerita ternyata mendorong siswa dalam kegiatan bercerita, dengan media audio visual anak bisa melihat langsung saat kegiatan bercerita karena media audio visual juga dapat mengeluarkan suara dan terlihat juga gambarnya. Media audio visual memang membutuhkan dana yang tidak sedikit, tetapi bagi guru yang mengajar di sekolah yang kurang memadai 
"Ceria"

Jurnal Program Studi Pendidikan Anak Usia Dini

dapat menggunakan barang-barang yang ada disekitar baik didalam dan diluar

kelas. Guru dalam setiap pembelajaran hendaklah menyiapkan terlebih dahulu pembelajaran tersebut, memikirkan apa yang akan dilakukan dikelas, agar pembelajarn tidak monton sehingga siswa tidak merasa bosan dan selalu bersemangat. Diyakini bahwa kemajuan suatu bangsa ditentukan oleh mutu pendidikan ditentukan oleh kualitas pembelajaran yang terjadi di kelas.

\section{Daftar Acuan}

Faridani, Lara \& Sri Wulan \& Sri Indah Pujiastuti. (2014). Evaluasi Perkembangan Anak Usia Dini. Tangerang Selatan: Universitas Terbuka

Hamdani. (2011). Strategi Belajar Mengajar. Bandung: Pustaka Setia.

Munadi, yudhi. (2013). Media Pembelajaran. Jakarta Selatan: GP Press Group

Peraturan Menteri Pendidikan dan Kebudayaan Nomor 137 Tahun 2014 Tentang Standar Nasional Pendidikan Anak Usia Dini.

Rahayu, A.Y. (2013). Menumbuhkan Kepercayaan Diri Melalui Kegiatan Bercerita. Jakarta: PT.Indeks.

Risaldy, Sabil. (2015). Bermain Bercerita Bernyanyi. Jakarta Timur: PT. Luxima Metro Media.

Sujiono, Y.N. (2009). konsep dasar pendidikan anak usia dini. Jakarta: PT.Indeks.

Susanto, Ahmad. (2011). Perkembangan Anak Usia Dini Pengantar Dalam Berbagai Aspeknya. Jakarta: Kencana. 